\title{
Economic Hardship Among Elderly and Its Consequences Toward Cognitive Status.
}

\author{
J., Masud \\ Malaysian Research Institute on Ageing \\ Universiti Putra Malaysia \\ 43400 Serdang Selangor \\ T. A., Hamid \\ Malaysian Research Institute on Ageing \\ Faculty of Human Ecology, Universit Putra Malaysia \\ 43400 Serdang Selangor.
}

\begin{abstract}
Objectives: The purpose of this study is to identify factors contributing to economic hardship and its consequences toward cognitive status among elderly in Malaysia. Design: the study is a cross-sectional study through personal interview. Setting: Data for this study were obtained from the project 'Identifying Psychosocial Risks and Quantifying the Economic Costs of Age-Related Cognitive Decline among Older Malaysians', funded by Malaysia Government through long term grant scheme (LRGS) in 2015. Participants: A total of 2321 elderly from Perak, Johor, Kelantan and Selangor state were involved in the study. Measurement: Economic hardship scale and MiniMental State Examination (MMSE) were used in this analysis. Logistic regression was conducted to identify factors that contribute toward economic hardship of elderly and a Chi-square analysis was used to examine the association between economic hardship and cognitive status. Results: Logistic regression revealed that four predictors significantly contributed toward explaining the likelihood of experiencing economic hardship. The factors were ethnicity, education level, sources of income and household poverty status. Malay, elderly with no formal schooling, those with no earned income and living in a poor household (household income less than RM930), were more likely to experience economic hardship than their counterpart. The chi-square analysis revealed that higher proportion of those experienced economic hardship were reported having cognitive impairments (severe, moderate and mild). Conclusion: The study provides new insight into the impact of economic hardship on cognitive status of older persons particularly in developing countries such as Malaysia.
\end{abstract}

Key Words: Economic Hardship, Financial Hardship, Cognitive Status, Cognitive Impairment, Elderly Malaysia

\section{INTRODUCTION}

The whole world is ageing at a faster rate than ever especially in developing countries (Shetty, 2012). According to the United Nation, percentages of elderly age 60 and above in Asia are expected to increase from $11.6 \%$ of the population in 2015 toward $24.6 \%$ by 2050 (United Nations, 2015). Consequently, Malaysia is projected to become an aged nation in 2030 (Ministry of Women, Family and Community Development, 2013). The increasing number of elderly over time is might be due to an improvement of Health care in Malaysia (Chan Yin-Fah, Masud et al., 2010). Older person defined as those aged 60 years old and above (Ministry of Women, Family and Community Development, 2013) who are living better living conditions and enjoyed improve health facilities have resulted in increased life expectancy. Life expectancy at birth for man and woman in Malaysia were 72.5 and 77.4 years old in 2015, an increase from 71.9 and 76.6 respectively in year 2010 (Department of Statistic Malaysia, 2015). 
Malaysians are expected to live much longer in old age. More resources are needed to support old age living. Changing family living patterns whereby family have small number of children contributed to the shrinking of the traditional financial and social support available to older persons. Based on fertility rate in Malaysia, total children born declined from three children in 1999 to 1.9 children in 2014 (The World Bank, 2016). Older person of today need to have own resources to support their old age. Unavailability of comprehensive social protection system put more pressure to people to have own resources to be used in old age.

With higher percentage of workers are in the informal sector as well as the increasing cost of living, many older persons are projected to become old without sufficient resources to support old age. According to Employees Provident Fund (EPF) Malaysia statistics in 2013 for elderly age 54 years old, $69 \%$ of them have less than RM50,000 to support old age living (EPF, 2015). This is worrying as the amount is not enough to support old age life for at least 20 years after retirement. Majority of the consumers nowadays, consume more than save (Gokhale, Kotliko, and Sablehaus 1996; Offer 2006). In addition, income received by elderly after they retired normally less than what they received while working (Masud, Haron et al., 2006).

Among old own account workers who did not have employee providence fund they normally have to work until they are unable to work to support their living. In general, elderly is one of the group that vulnerable to poverty (Ahmad, Mansor and Paim, 2016), which may lead them to experienced economic hardship. No old age planning (Noone, Stephens and Alpass, 2009), increase cost of living (Hossain, Byrne et al., 2011), migration of children (Guo, Aranda and Silverstein, 2009) lack of financial resources (Bell, Nelson et al., 2014), difficulties to meet daily needs such as food, medical expenses, transportation (Tay and Diener, 2011), no money (Ahmad, Mansor and Paim, 2016), unable to buy needed items, have to rely on others, unable to get goods and services needed may can lead to economic hardship which may affect their wellbeing. According to Rojas (2008), poor people are commonly have lower well-being than non-poor. Inabilities to meet daily needs may leads to starvation conditions and worry which eventually may cause depression or economic hardship. According to previous studies, economic hardship leads toward various psychological distresses among elderly such as depression, anxiety, and suicidal ideation (Almeida, Draper et al., 2012; Pudrovska, Schieman et al. 2005; Bierman 2014). Economic hardship was proven to be the factors that causing depression among elderly in Asia (Li, 1995). Unfortunately, there is not study among Malaysian regarding this matter. Thus, this study will attempt to examine factors explaining the likelihood of experiencing economic hardship and explore its association between economic hardships with cognitive status of the elderly. Much study has been done on poverty (Samat, Elhadary et al., 2012; Barrientos, Gorman and Heslop, 2003) but there has been no study exploring the relationship between economic hardship and cognitive status of the elderly in Malaysia. Results from this study will provide some insight on impact of economic hardship on elderly cognitive status. Knowledge about the relationship between economic hardship and cognitive status can be useful in designing programs to enhance the wellbeing of older person. Therefore, the research questions and objective of this paper as below:

\section{Research questions}

1. What are the factors explaining the likelihood of older person experiencing economic hardship?

2. Is there an association between economic hardship experience and cognitive status? 


\section{Research objectives}

1. To determine factors explaining the likelihood of older person experiencing economic hardship

2. To examine the association between economic hardship experience and cognitive status

\section{Economic hardship}

\section{LITERATURE REVIEW}

Economic hardship can be defined as lack of money to support basic necessities for household such as food, clothing, shelter and medical care (Mirowsky and Ross, 2001). In this study, the term economic hardship are used interchangeably with financial hardship because of both term caught the same concept. Elderly with less economic hardship can be reflect as having less dependents and needs, fewer interest in possess the material things or increases the support of government (Mirowsky and Ross, 1999). Some of prior studies explained that economic hardship might be decline with age due to the maturity in conducting their life (Levecque, Rossem et al., 2011). In contrary, it does not only mean that but elderly also have less of opportunities to recover if fall into bad economic situations (Levecque, Rossem et al., 2011). Therefore, it is important for them to manage their economic situations carefully in order to avoid experiencing economic hardship.

Based on previous studies, social (ethnicity, living arrangement and education level) (Anderson and Becker, 1999; Srivastava and Mohanty, 2012; Maes, 2013; Mohd, 2014) and economic factors (sources of income and household income) of the elderly are some of the factors contribute toward experiencing economic hardship among elderly. Within the context of Malaysia history, there were three main ethnic consist of Malay, Chinese and Indian reside in Malaysia. Malay is the largest ethnic group in Malaysia followed by Chinese and Indian. Each ethnic has its own sociocultural values that they protect such as religion, language, dress and food (Tey, Siraj et al., 2015). Bumiputeras (consists of Malay and indigenous people) elderly were the most common group entered the poverty, hence vulnerable to economic hardship compared with Chinese and Indian (Mohd, 2014). This might due to majority of Malay elderly live in rural areas compared to other ethnic which avoid them to expose toward economic opportunities. According to WHO study, Malaysian elderly living in rural areas experiencing greater financial hardship than elderly living in urban area (Shahar, Earland and Abd Rahman, 2001). Hence, possibilities for Malay elderly experiencing economic hardship compared to other ethnicities are higher. In term of living arrangement, elderly in Malaysia are commonly co-residing with their children and living in an extended family (Mohd, 2014). However, industrialization, urbanization and modernization nowadays had broken-down the extended families (Chan, 2006). The elderly that living alone or with spouse were prone to high cost of living and have the potential of living in poverty (Sherlock, 2000). Education also influences the economic hardship experience of the elderly. Prior study reveals that, elderly with lower education level have probability living in poverty (Mohd, 2014).

Economic factors such as sources and amount of household income also played an important role in effecting economic hardship of elderly. Prior study reveals that most of elderly received income from social income (e.g. children and relatives) followed by working income (Masud and Haron, 2014). Unfortunately, the numbers of children are getting fewer day by day. Thus, elderly have tendency to experience economic hardship if they solely depend on social income to support their life. Study by Hamid and Samah (2000) reveals that $10 \%$ of elderly living in Johor, Malaysia are found living with inadequate income to support their life. Despite living with inadequate income, elderly generally felt that they have enough income to support their life (Stoller and Stoller, 2003) even though their income are relatively low (Masud, Haron et al., 2006). Financial resources especially money are important as it will directly influence one's 
purchasing power and wellbeing. In brief, social and economic factors are both played an important role toward experiencing economic hardship among elderly. Thus, this study attempt to examine social and economic factors namely; ethnicity, living arrangement, education, sources and amount of household income in explaining economic hardship.

\section{Cognitive State}

Interest to study on elderly health is on the increase with increasing life expectancy. One of the important health issues on aspect of wellbeing is cognitive health (Oxley, 2009). It is critical to study elderly cognitive state because it could affect elderly quality of life (Fillit, Butker et al., 2002). According to Fors, Lennartsson and Lundberg (2009), cognitive health of elderly can weaken due to the normal process of aging or pathological changes. Example for pathological changes that can contribute toward elderly cognitive impairment is dementia (Sherina, Rampal and Mustaqim, 2004). Dementia could cause the memory disturbance and behavioral changes for elderly such as depression (Sherina, Rampal and Mustaqim, 2004) and will eventually effecting their wellbeing in late life.

However, Kiely, Leach et al. (2015) stated that the risk on having cognitive impairments also greater if they experience hardship. The hardship experiences by an individual are consistent with age (Butterworth, Rodgers and Windsor, 2009). It means that the older a person become the more hardship they will experience. Moreover, economic hardship are found to be one of critical stressor that effecting the quality of lives of an individual and families (Edin and Kissane, 2010; Seccombe, 2000). It is proven to be one of the factors related toward cognitive state of elderly (Stephens, Alpass and Towers, 2010). Study in UK revealed that economic inequalities experienced by elderly in UK due to working life could also affect their cognitive state (Chandola, Ferrie et al., 2007). Majority of them experienced it in early retirement age. On the other hand, study by Butterworth, Rodgers and Windsor (2009) on financial hardship, revealed that respondents with deprivation feeling and reported having cash flow problems have more potential to experience mental health problems than their counterpart. Human body function such as hearing, vison, movement and mental sharpness will slowly decreasing over time. Although the elderly health are known to be decreasing day by day, the hardship they experience in late life are afraid to be a factor that could trigger their cognitive impairment.

\section{RESEARCH FRAMEWORK}

The study adopted the Family resource management model proposed by Deacon and Firebaugh in 1981. This model was used to explained family and managerial concept. According to Deacon and Firebaugh (1981), family is viewed as a system. It consists of three major components; input, throughput and output. Inputs consist of demand and resources. The resources (social and economic) will be used to meet the needs of older person. The sociodemographic background such as ethnicity, living arrangement and education will have an effect on the ability to meet daily needs. Availability of income (sources and amount) will determine older persons' ability to obtaine goods and services. Lack or excess to economic resources may hinder older persons' ability to meet their needs hence experiencing economic hardship. The economic hardship experience will eventually leads toward worry, stress or depression which in the long run eventually may affect their cognitive status. Lastly at the output level, economic hardship experienced by elderly could influence the cognitive states of elderly. Cognitive impairment is selected to be representing the output of the model. Figure 1 explained research framework of the study. 
INPUT

\begin{tabular}{|c|} 
SOCIO- \\
DEMOGRAHPIC \\
Ethnicity \\
Living Arrangement \\
Education \\
Sources of Income \\
Household Poverty \\
Status \\
\hline
\end{tabular}

THROUGHPUT

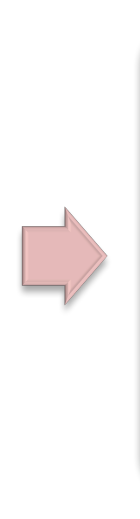

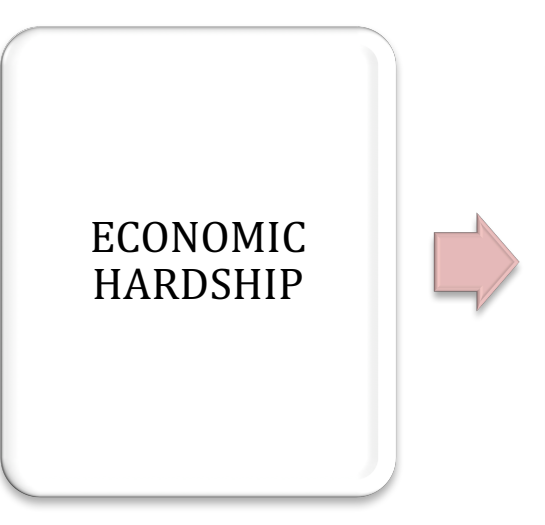

OUTPUT

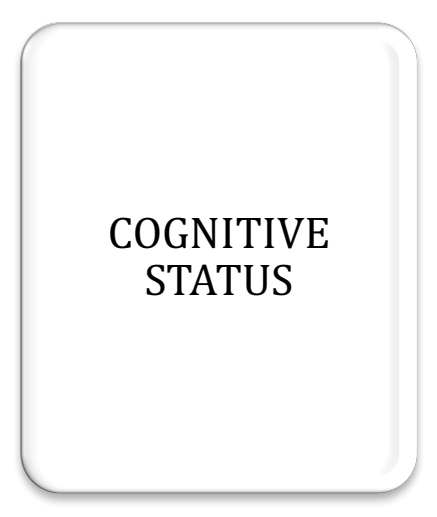

THE DATA

The data for this study were obtained from the project entitle 'Identifying Psychosocial Risks and Quantifying the Economic Costs of Age-Related Cognitive Decline among Older Malaysians' funded by Malaysia Government long term grant scheme (LRGS) in 2015. The study was conducted in Perak, Johor, Kelantan and Selangor states with the highest percentage of older persons in Malaysia. The respondents comprised of older persons age 60 years old and above. Multi-stage stratified random sampling was used to select the samples. A total of 2321 respondents involved in this study. Data were collected by trained enumerators through face to face interview. Economic hardship scale was developed through focus group discussion among older Malaysian. The scale comprised of a total of 11 statements with three choices of answer which are ever, never and not relevant. The economic hardship scale captured the economic hardship situations experienced by elderly in the past six months which includes situations with no money to obtain their wants and needs and depending on other people. Those ever experienced any one of the 11 statements listed were considered to be experiencing economic hardship. Cognitive impairment was measured using Mini-Mental State Examination (MMSE). This scale measured the cognitive function among elderly. The MMSE, comprised of six sections namely; time orientation (score 0 to 5), place orientation (score 0 to 5 ), memory registration (score 0 to 3 ), attention or concentration (score 0 to 5), memory (score 0 to 3 ) and language (score 0 to 9 ). The total score ranging from zero to thirty were regroup into four levels; severe (total score of less than 10), moderate (10 to 18), mild (19 to 23) and normal (more than 24). Binary logistic regression and chi-square analysis were used in the data analysis. The dependent variables for binary logistic regression was economic hardship while independent variables were ethnicity (Malay and Non-Malay); education level (no schooling; primary; and secondary and higher), living arrangement (living alone and living with other people), sources of income (income received from work related and social) and household poverty status (poor and non-poor). Income from work related were wages, businesses and agricultural. Meanwhile social related income were income received from transfer such as children's remittance and welfare assistance. Household poverty status were divided into two categories based on Malaysia poverty line in general for Peninsular Malaysia (EPU, 2014). Respondents with household monthly income less than RM930 were considered poor household while respondents with household income more than RM930 were considered non-poor household. For ease of interpretation for independent variables, all odds ratio with negative beta (B) will be inversed by using formula of 1 divide by odds ratio.

\section{Socio-economic Background of Respondents}

\section{RESULTS}

The background of respondents is shown in Table 1. Majority of respondents in this study were Malay (62.3\%) while the rest are all non-Malay. This reflect the general trend in population structure of the country. Most of the respondents co-reside (65.8\%) and 34.2\% were living 
alone or with spouse. More than half of the respondents had only up to primary schooling $(55.3 \%)$ followed by secondary and higher $(23.6 \%)$. There were $21.1 \%$ respondents' with no schooling.

Respondents in this study were mostly receiving income from social sources (52.9\%) such as children's remittance and welfare assistance. Less than half (44.3\%) received income from work related sources such as wages, business and agriculture. Majority of respondents (55.9\%) were living in household with income below poverty line (general poverty line in peninsular Malaysia is RM930) (EPU, 2014). Consequently, less than half of the respondents were living in a non-poor household (44.1\%).

Table 1: Socio-Economic Background of Respondents

\begin{tabular}{lcc}
\hline Variables & $\mathrm{N}$ & $\%$ \\
\hline \hline Ethnicity & 1447 & 62.3 \\
$\circ \quad$ Malay & 875 & 37.7 \\
$\quad$ Non-Malay & & \\
Living Arrangement & 795 & 34.2 \\
$\quad \quad$ Alone or With spouse & 1527 & 65.8 \\
$\quad \quad$ With Others & 490 & 21.1 \\
Education & 1283 & 55.3 \\
$\quad$ No Schooling & 549 & 23.6 \\
$\quad \circ$ Primary & 1205 & 53.0 \\
$\quad \quad$ Secondary and Higher & 1008 & 44.3 \\
Sources of Income & & \\
$\quad$ Social & 1269 & 55.9 \\
$\quad$ Working & 1001 & 44.1 \\
HH Poverty Status & Poor &
\end{tabular}

\section{Economic Hardship experienced by elderly}

The economic hardship in this study was measured to capture the elderly experienced resulted from lacks of economic resources. Table 2 shows the economic hardship experienced by elderly by their socio-economic background. Economic hardship experienced by elderly were different based on their ethnicity, education level and household poverty status. More Malay elderly reported experienced economic hardship compared to non-Malay elderly. Malay or Bumiputras are known to be vulnerable toward poverty compared to other ethnic (Mohd, 2014). Thus, they have probability of experiencing economic hardship due to insufficient money. Elderly living with others were reported to experience economic hardship more than elderly living alone or with spouse. Elderly living with other people in the household need to 
consider other people before obtaining what they want. Limited resources also need to be shared with younger family members. Thus, they may experience the pressure which consequently increasing possibilities of experiencing economic hardship. Higher percentages of elderly with lower education level (no schooling and primary) experienced economic hardship than elderly with secondary or higher education level. In line with previous study, an improved of education were found to increase an individual quality of life (Winters, 2011). Elderly living in poor household are reported experiencing economic hardship than elderly living in non-poor household. Poor household could be the obstacle for elderly to obtained their wants and need which leads toward economic hardship.

Table 2 : Result on chi-square analysis on Socio-economic Background and Economic Hardship

\begin{tabular}{|c|c|c|c|}
\hline \multirow[t]{3}{*}{ Variables } & \multicolumn{2}{|c|}{ Economic Hardship } & \multirow{3}{*}{ Chi-square } \\
\hline & Yes & No & \\
\hline & $\mathrm{N}(\%)$ & $\mathrm{N}(\%)$ & \\
\hline \multicolumn{4}{|l|}{ Ethnicity } \\
\hline Malay & $349(24.1)$ & $1098(75.9)$ & $\chi^{2}=36.622$ \\
\hline Non-Malay & $120(13.7)$ & $755(86.3)$ & $\begin{array}{l}d f=1 \\
\text { Sig- } p=.000\end{array}$ \\
\hline \multicolumn{4}{|l|}{ Living Arrangement } \\
\hline Alone or with spouse & $156(19.6)$ & $639(80.4)$ & $\chi^{2}=.248$ \\
\hline With others & $313(20.5)$ & $1214(79.5)$ & $\begin{array}{l}d f=1 \\
\text { Sig- } p=.618\end{array}$ \\
\hline \multicolumn{4}{|l|}{ Education } \\
\hline No Schooling & $130(26.5)$ & $360(73.5)$ & $\chi^{2}=35.889$ \\
\hline Primary & $273(21.3)$ & $1010(78.7)$ & $d f=2$ \\
\hline Secondary and Higher & $66(12.0)$ & $483(88.0)$ & Sig- $p=.000$ \\
\hline \multicolumn{4}{|l|}{ Household Poverty Status } \\
\hline Poor & $337(26.6)$ & $932(73.4)$ & $\chi^{2}=61.019$ \\
\hline Non-poor & $132(13.2)$ & $869(86.8)$ & $\begin{array}{l}d f=1 \\
\text { Sig- } p=.000\end{array}$ \\
\hline
\end{tabular}

\section{Cognitive status of elderly}

Table 3 shows that elderly cognitive impairment were differ by ethnicity, education level and household poverty status. The study revealed that more than half (54.7\%) of Malay elderly had cognitive impairment (severe, moderate and mild). Contrary, majority of non-Malay elderly in a normal cognitive state $(57.8 \%)$. There were no differences in cognitive status between elderly living alone or with spouse and living with others. Among those experiencing cognitive impairment, majority of the elderly were not having formal schooling (73.6\%) compared to respondents with primary (50.1\%) or secondary and higher education level (29\%). Living conditions also played an important role in elderly cognitive status. Majority of elderly living in poor household (58.6\%) reported having cognitive impairment compared to elderly living in non-poor household (38.9\%). It can be concluded that elderly who are Malay, having no formal schooling and living in poor household condition have high tendency to experience cognitive impairment. 
Table 3: Result on chi-square analysis on Socio-economic Background and Cognitive Status

\begin{tabular}{|c|c|c|c|c|c|}
\hline \multirow[t]{3}{*}{ Variables } & \multicolumn{4}{|c|}{ Cognitive Status } & \multirow[t]{3}{*}{ Chi-square } \\
\hline & Severe & Moderate & Mild & Normal & \\
\hline & $\mathrm{N}(\%)$ & $\mathrm{N}(\%)$ & $\mathrm{N}(\%)$ & $\mathrm{N}(\%)$ & \\
\hline \multicolumn{6}{|l|}{ Ethnicity } \\
\hline Malay & $24(1.7)$ & $260(18.2)$ & $497(34.8)$ & $646(45.3)$ & \multirow{2}{*}{$\begin{array}{l}\chi^{2}=41.64 \\
d f=3 \\
\text { Sig- } p=.000\end{array}$} \\
\hline Non-Malay & $24(2.8)$ & $106(12.3)$ & $234(27.1)$ & $498(57.8)$ & \\
\hline \multicolumn{6}{|c|}{ Living Arrangement } \\
\hline $\begin{array}{l}\text { Alone or with } \\
\text { spouse }\end{array}$ & $18(2.3)$ & $123(15.7)$ & $259(33.0)$ & $384(49.0)$ & \multirow{2}{*}{$\begin{array}{l}\chi^{2}=.98 \\
d f=3 \\
\text { Sig- } p=.805\end{array}$} \\
\hline With others & $30(2.0)$ & $243(16.1)$ & $472(31.4)$ & $760(50.5)$ & \\
\hline \multicolumn{6}{|l|}{ Education } \\
\hline No Schooling & $26(5.4)$ & $163(33.8)$ & $166(34.4)$ & $127(26.3)$ & \multirow{3}{*}{$\begin{array}{l}\chi^{2}=290.64 \\
d f=6 \\
\text { Sig- } p=.000\end{array}$} \\
\hline Primary & $16(1.3)$ & $173(13.7)$ & $444(35.1)$ & $633(50.0)$ & \\
\hline $\begin{array}{l}\text { Secondary and } \\
\text { Higher }\end{array}$ & $6(1.1)$ & $30(5.5)$ & $121(22.4)$ & $384(71.0)$ & \\
\hline \multicolumn{6}{|c|}{$\begin{array}{l}\text { Household Poverty Status } \\
\text { Poor }\end{array}$} \\
\hline Non-poor & $\begin{array}{l}26(2.1) \\
18(1.8)\end{array}$ & $\begin{array}{l}268(21.3) \\
95(9.6)\end{array}$ & $\begin{array}{l}442(35.2) \\
272(27.5)\end{array}$ & $\begin{array}{l}520(41.4) \\
604(61.1)\end{array}$ & $\begin{array}{l}\chi^{2}=100.32 \\
d f=3 \\
\text { Sig- } p=.000\end{array}$ \\
\hline
\end{tabular}

\section{Factors Explaining the Likelihood of Respondents Experiencing Economic Hardship}

Binary logistic regression was conducted to determine the likelihood of experiencing economic hardship by ethnicity, living arrangement, education level, sources of income, household poverty status. The result of the analysis is shown in Table 4 . The model was statistically significant $\chi 2(7, \mathrm{~N}=2270)=163.067, \mathrm{p}<.001$. The model can significantly distinguish between elderly experiencing economic hardship and those who did not experience economic hardship. The Nagelkerke $\mathrm{R}^{2}$ score was 0.108 while Cox and Snell $\mathrm{R}^{2}$ score was .069 . Four predictors (ethnicity, income from working, household poverty status and education level) significantly contribute toward explaining the model.

The first significant predictors for economic hardship was ethnicity with odds ratio of 2.21. The data showed that the Malays elderly had 2.21 times more likelihood of having economic hardship compared to Non-Malay elderly. This result is in line with Mohd (2014) which stated that Bumiputras elderly in Malaysia (consist of Malay and indigenous people) are the most vulnerable group to enter poverty.

The second significant predictor was education level. Elderly with no education had 1.56 times more likelihood of experiencing economic hardship than elderly with secondary or higher education level. The result revealed that elderly with higher education level has less likelihood of having economic hardship. Better educational achievement are already proven to be the ticket for an individual to obtained better income which help them avoiding the poverty (Mohd, 2014). Household poverty status was found significantly contribute toward explaining economic hardship. 
Elderly sources of income significantly explain economic hardship. Elderly with no work related income were 0.96 time more likelihood of experiencing economic hardship than elderly who received income from work. The data reveal that elderly who work have lower risk of experiencing economic hardship. Study by Sherlock (2000) also reveal that the elderly who have reduced capacity of income generation or did not work will leads toward poverty. Elderly are known to receive lower income compared to younger people (Behanova, Katreniakova et al., 2015). This is due to the retirement (Masud, Haron et al., 2006) which lessen their amount of income received. Consequently, the elderly were more prone toward poverty compared to younger people. Elderly living in a poor household were 1.79 times more likelihood of experiencing economic hardship compared to elderly living in a non-poor household. Non-poor household was expected to be able to fulfilled basic daily needs of the members including older person. In contrast, those living in poor household may experience difficulty in meeting basic needs.

Though living arrangement has been recognized to have influence on the wellbeing of elderly (Zhang, 2015), living arrangement did not significantly contribute toward economic hardship. The data show that the economic situations of the household is more critical in explaining economic hardship compared to living arrangement.

Table 4: Factors Explaining the Likelihood of Respondents Experience Economic Hardship

\begin{tabular}{|c|c|c|c|c|}
\hline \multirow{2}{*}{ Variables } & \multicolumn{4}{|c|}{ Economic Hardship } \\
\hline & B & SE B & Sig & Odds Ratio \\
\hline $\begin{array}{l}\text { Ethnicity } \\
\text { (Ref: Non-Malay) }\end{array}$ & 0.793 & 0.121 & 0 & 2.211 \\
\hline \multicolumn{5}{|l|}{$\begin{array}{l}\text { Living Arrangement (Ref: } \\
\text { With others) }\end{array}$} \\
\hline Alone or with spouse & -0.081 & 0.115 & 0.48 & 0.922 \\
\hline \multicolumn{5}{|l|}{ Education (Ref: } \\
\hline \multicolumn{5}{|l|}{ No schooling) } \\
\hline Primary & -0.166 & 0.129 & 0.199 & 0.847 \\
\hline Secondary and Higher & -0.447 & 0.181 & 0.014 & 0.64 \\
\hline \multicolumn{5}{|l|}{ Sources of Income } \\
\hline Social (Ref: No) & -0.419 & 0.244 & 0.085 & 0.658 \\
\hline Working (Ref: No) & -1.184 & 0.255 & 0 & 0.306 \\
\hline \multicolumn{5}{|l|}{$\begin{array}{l}\text { HH Poverty Status (Ref: } \\
\text { Poor) }\end{array}$} \\
\hline Non-Poor & -0.579 & 0.123 & 0 & 0.56 \\
\hline$\chi^{2}$ & \multicolumn{4}{|c|}{163.067} \\
\hline Df & \multicolumn{4}{|c|}{7} \\
\hline Cox and Snell & \multicolumn{4}{|c|}{0.069} \\
\hline Nagelkerke $\mathrm{R}^{2}$ & \multicolumn{4}{|c|}{0.108} \\
\hline
\end{tabular}

\section{Association between Economic Hardship and Cognitive Impairment}

An older person experienced economic hardship when he or she unable to meet basic daily needs. Such experience can cause worry, stress or depression which consequently may affect their cognitive status. Table 5 showed descriptive results of MSSE scale items and economic hardship; and chi-square analysis between cognitive status and economic hardship. The table 
clearly shows that the mean score for MSSE scale that differ significantly were attention or concentration and memory. Higher proportion of elderly who did not experienced economic hardship had high attention or concentration and good memory. It is explained that both attention or concentration and memory are an important traits that will help elderly in managing themselves economically to avoid economic hardship. The chi-square analysis indicated that there was a significant difference in cognitive status among those experiencing economic hardship and those who did not experience economic hardship $\left(\chi^{2}=53.818, p=.000\right)$. Majority of elderly with economic hardship were having cognitive impairment (severe, moderate and mild) rather than normal state of cognitive. Almost two third (63.1\%) of elderly who experienced economic hardship reported having cognitive impairment (severe, moderate and mild). In line with the study, Stephens, Alpass and Towers (2010) also found that social factors such as economic hardship had an effect on mental health of the elderly. An individual with financial hardship tend to suffer cognitive impairment due to exposure on financial stressors such as difficulty in paying bills and fulfilling their wants and need (Bradshaw and Ellison, 2010). The cumulative stress experiencing by elderly can eventually effecting cognitive function in short and long term (Scott, Graham-Engeland et al., 2015). Thus, older person should have sufficient economic resources to avoid them from experienced economic hardship which eventually may effect their cognitive impairment.

Table 5: Result on chi-square analysis on Economic Hardship and Cognitive Status

\begin{tabular}{lcc}
\hline & \multicolumn{2}{c}{ Economic Hardship } \\
\cline { 2 - 3 } & $\begin{array}{c}\text { Yes }(\mathrm{n}=469) \\
\text { Mean }\end{array}$ & $\begin{array}{c}\text { No }(\mathrm{n}=1853) \\
\text { Mean }\end{array}$ \\
\hline \hline $\begin{array}{l}\text { Cognitive State (MSSE Scale) } \\
\text { Time Orientation }\end{array}$ & 4.056 & \\
Place Orientation & 4.598 & 4.367 \\
Memory Registration & 2.927 & 4.699 \\
Attention or Concentration & 0.780 & 2.906 \\
Memory & 0.631 & 0.870 \\
Language & 0.994 & 0.716 \\
Cognitive State (MSSE Score) & & 0.999 \\
Severe & $0.030(3.0 \%)$ & $0.019(1.9 \%)$ \\
Moderate & $0.25(25.0 \%)$ & $0.137(13.7 \%)$ \\
Mild & $0.352(35.1 \%)$ & $0.311(31.1 \%)$ \\
Normal & $0.369(36.9 \%)$ & $0.533(53.3 \%)$ \\
\hline Chi-Square & $\chi^{2}=53.818 d f=3$ & Sig- $p=.000$ \\
\hline \hline
\end{tabular}

\section{CONCLUSIONS}

This study examines the factors that contribute toward economic hardship and its effect toward cognitive impairment of elderly. The study found that several social and economic factors such as ethnicity, education level, work related income and household poverty status contributed toward explaining economic hardship among elderly. Elderly who are Non-Malay, had secondary or higher education level, non-poor and received income from working were reported to experience less economic hardship than the counterpart. The results showed that these factors significantly determine an elderly economic hardship. Looking at relationship between economic hardship and cognitive impairment, it reveals that elderly with economic hardship were suffering severe to mild cognitive impairment. Even though results showed that some elderly with economic hardship have normal cognitive, the percentage was smaller than elderly with severe, moderate and mild cognitive impairment. Hence, it can be concluded that 
economic hardship could be one of the factor that accelerates cognitive impairment of elderly. With increase longevity and decline in human body functioning, it may leads to more year's unhealthy life for elderly. Thus, it is important for an individual to prepare themselves economically before they entered retirement age in order to lessen the potential of experiencing economic hardship which may lead to cognitive impairment in late life. Finding from this study, provide some evidence on the relationship between economic hardship and cognitive impairment which becoming an increasing concern among elderly. Therefore, it is belief that this finding provided intial findings on the consequence of economic hardship on cognitive status of elderly particularly in Malaysia. Further study which focus on psychological aspects should be conducted in near future.

\section{References}

Ahmad, N. F., Mansor, M., \& Paim, L. (2016). Income Poverty and Well-Being among Vulnerable Households: A Study in Malaysia. Asian Social Science, 12(2), 195.

Almeida, O. P., Draper, B., Snowdon, J., Lautenschlager, N. T., Pirkis, J., Byrne, G., ... \& Pfaff, J. J. (2012). Factors Associated with Suicidal Thoughts in a Large Community Study of Older Adults. The British Journal of Psychiatry,201(6), 466-472.

Barrientos, A., Gorman, M., \& Heslop, A. (2003). Old Age Poverty in Developing Countries: Contributions and Dependence in Later Life. World Development, 31(3), 555-570.

Behanova, M., Katreniakova, Z., Nagyova, I., van Ameijden, E. J., van Dijk, J. P., \& Reijneveld,S. A. (2015). Elderly from Lower Socioeconomic Groups are more Vulnerable to Mental Health Problems, but Area Deprivation does not Contribute: A Comparison between Slovak and Dutch Cities. The European Journal of Public Health, ckv096.

Bell, M. M., Nelson, J. S., Spann, S. M., Molloy, C. J., Britt, S. L., \& Goff, B. S. N. (2014). The Impact of Financial Resources on Soldiers' Well-Being. Journal of Financial Counseling and Planning, 25, 41-52.

Bierman, A. (2014). Reconsidering the Relationship between Age and Financial Strain among Older Adults. Society and Mental Health, 4(3), 197-214.

Butterworth, P., Rodgers, B., \& Windsor, T. D. (2009). Financial Hardship, Socio-Economic Position and Depression: Results from the PATH through Life Survey. Social science \& medicine, 69(2), 229-237.

Bradshaw, M., \& Ellison, C. G. (2010). Financial Hardship and Psychological Distress: Exploring the Buffering Effects of Religion. Social science \& medicine, 71(1), 196-204.

Chan, K. W. (2006, July). Rethinking Asian Welfare Model: Social Development or Risk Production?. In Third East Asian Social Policy Research Network International Conference on GDPism and Risk: Challenges for Social Development and Governance.

Chandola, T., Ferrie, J., Sacker, A., \& Marmot, M. (2007). Social Inequalities in Self Reported Health in Early Old Age: Follow-Up of Prospective Cohort Study. BMJ, 334(7601), 990. doi: 10.1136/ bmj.39167.439792.55.

Deacon, R. \& Firebaugh, F. (1981). Family Resources Management: Principles and Applications. Boston: Allyn \& Bacon, Inc.

Department of Statistic Malaysia (2015). Abridged Life Tables, Malaysia, 2012 - 2015.

https://www.statistics.gov.my/index.php?r=column/pdfPrev\&id=cWxzRWcvMTZrWFp4UStqQmp3MG9QZz09. Accessed 1 May 2016

Edin, K., \& Kissane, R. J. (2010). Poverty and the American Family: A Decade in Review. Journal of Marriage and Family, 72, 460-479.

Employees Provident Fund (2015). Epf Savings and your Retirement.

http://www.kwsp.gov.my/portal/documents/10180/4459038/BOOK_-

EPF_Saving_and_Your_Retirement_CS5_.pdf. Accessed 1 May 2016.

Fillit, H. M., Butler, R. N., O'Connell, A. W., Albert, M. S., Birren, J. E., Cotman, C. W., ... \& Perls, T. T. (2002, July).

Achieving and Maintaining Cognitive Vitality with Aging. In Mayo Clinic Proceedings (Vol. 77, No. 7, pp. 681-696).

Elsevier.

Fors, S., Lennartsson, C., \& Lundberg, O. (2009). Childhood Living Conditions, Socioeconomic Position in Adulthood, and Cognition in Later Life: Exploring the Associations. The Journals of Gerontology Series B: Psychological Sciences and Social Sciences, 64(6), 750-757. 
Gokhale, Jagadeesh, Laurence J. Kotlikoff, and John Sabelhaus. 1996. Understanding the Postwar Decline in US Saving: A Cohort Analysis. Brookings Papers on Economic Activity 1:315-90.

Guo, M., Aranda, M. P. and Silverstein, M. (2009) 'The Impact of Out-Migration on the Inter-Generational Support and Psychological Wellbeing of Older Adults in Rural China', Ageing and Society, 29/7: 1085-104.

Hamid, T. A \& Samah, A. A., (2000). Kajian Persepsi Masalah dan Keperluan Warga Tua Johor, UPM-Yayasan Pembangunan Keluarga Johor Darul Takzim.

Hossain, N., Byrne, B., Campbell, A., Harrison, E., McKinley, B., \& Shah, P. (2011). The Impact of the Global Economic Downturn on Communities and Poverty in the UK. York: Joseph Rowntree Foundation.

Kiely, K. M., Leach, L. S., Olesen, S. C., \& Butterworth, P. (2015). How Financial Hardship is Associated with the Onset of Mental Health Problems Over Time. Social Psychiatry and Psychiatric Epidemiology, 50(6), 909-918.

Levecque, K., et al. (2011). Economic Hardship and Depression Across the Life Course: The Impact of Welfare State Regimes. Journal Health Social Behaviour. 52(2), 262-276.

Li, L. (1995). Subjective Well-Being of Chinese Urban Elderly. International Review of Modern Sociology, 25(2), 17-

26. Retrieved from http://www.jstor.org/stable/41421083

Maes, M. (2013). Poverty Persistence among the Elderly in the Transition from Work to Retirement. Journal of Economic Inequality. 11, 35-56.

Masud, J., Haron, S. A., Hamid, T. A., \& Zainaludin, Z. (2006). Economic Well Being of the Elderly: Gender Differences. Consumer Interest Annual, 56, 426-431.

Masud, J. and S. A. Haron (2014). Income Disparity among Older Malaysians. Research in Applied Economics. 6(2): 116.

Ministry of Women, Family and Community Development (2013). Active Ageing in Malaysia.

http://www.mhlw.go.jp/stf/shingi/2r98520000036yla-att/2r98520000036yqa_1.pdf. Accessed 1 May 2016.

Mirowsky, J., \& Ross, C. E. (2001). Age and the Effect of Economic Hardship on Depression. Journal of Health and Social Behavior. 132-150.

Mirowsky, J. and Ross, C. E. (1999). Economic Hardship across the Life Course. American Sociological Review. 64, 548-69.

Mohd, S. (2014, June). Poverty Issues among Malaysian Elderly. In Proceeding of the Social Sciences Research ICSSR 2014. (e-ISBN 978-967-11768-7-0).

Noone, J. H., Stephens, C., \& Alpass, F. M. (2009). Preretirement Planning and Well-Being in Later Life a Prospective Study. Research on Aging, 31(3), 295-317.

Offer, A. (2006). The Challenge of Affluence: Selfcontrol and Well-being in the United States and Britain Since 1950. Oxford, UK: Oxford University Press.

Oxley, H. (2009). Policies for Healthy Ageing. http://www.oecd-ilibrary.org/social-issues-migrationhealth/policies-for-healthy-ageing_226757488706. Accessed 1 May 2016.

Pudrovska, T., Schieman, S., Pearlin, L. I., \& Nguyen, K. (2005). The Sense of Mastery as a Mediator and Moderator in the Association between Economic Hardship and Health in Late Life. Journal of Aging and Health, 17(5), 634660.

Rojas, M. (2008). Experienced Poverty and Income Poverty in Mexico: A Subjective Well-Being Approach. World Development, 36(6), 1078-1093.

Samat, N., Elhadary, Y. A. E., Hijles, F. M., Ghazali, S., \& Sirat, M. (2012). Poverty and Deprivation: Using Geographic Information System in Evaluating the Accessibility of Households to Food Retailers in Penang State, Malaysia. $e$ BANGI, 7(2), 328.

Scott, S. B., Graham-Engeland, J. E., Engeland, C. G., Smyth, J. M., Almeida, D. M., Katz, M. J., ... \& Sliwinski, M. J. (2015). The Effects of Stress on Cognitive Aging, Physiology and Emotion (ESCAPE) project. BMC psychiatry, 15(1), 146.

Lloyd-Sherlock, P. (2000). Old Age and Poverty in Developing Countries: New Policy Challenges. World Development, 28(12), 2157-2168.

Shahar, S., Earland, J., \& Abd Rahman, S. (2001). Social and health profiles of rural elderly Malays. Singapore medical journal, 42(5), 208-213. 
Seccombe, K. (2000). Families in Poverty in the 1990s: Trends, Causes, Consequences, and Lessons Learned. Journal of Marriage \& the Family, 62, 1094-1113.

Sherina, M. S., Rampal, L., \& Mustaqim, A. (2004). Cognitive Impairment among the Elderly in a Rural Community in Malaysia. Medical Journal of Malaysia, 59(2), 252-257.

Sherlock, P. L. (2000). Old Age and Poverty in developing Countries: New Policy Challenges. World Development, 28(12), 2157-2168.

Shetty, P. (2012). Grey Matter: Ageing in Developing Countries. The Lancet, 379(9823), 1285-1287. http://doi.org/10.1016/S0140-6736(12)60541-8

Srivastava, A. \& Mohanty, S.K.. Poverty among Elderly in India. Social Indicator Research. 109(3):493-514

Stephens, C., Alpass, F., \& Towers, A. (2010). Economic Hardship among Older People in New Zealand: The Effects of Low Living Standards on Social Support, Loneliness, and Mental Health. New Zealand Journal of Psychology, 39(2), 49-55.

Stoller, M. \& Stoller, E. P (2003). Perceived Income Adequacy among Elderly Retirees. The Journal of Applied Gerontology, 22 (2), 230-251

Tay, L., \& Diener, E. (2011). Needs and Subjective Well-Being around the World. Journal of personality and social psychology, 101(2), 354.

Tey, N. P., Siraj, S. B., Kamaruzzaman, S. B. B., Chin, A. V., Tan, M. P., Sinnappan, G. S., \& Müller, A. M. (2015). Aging in Multi-Ethnic Malaysia. The Gerontologist, gnv153.

The World Bank (2016). Fertility Rate, Total (Births per Woman).

http://data.worldbank.org/indicator/SP.DYN.TFRT.IN/. Accessed 1 May 2016.

United Nations, Department of Economic and Social Affairs, Population Division (2015). World Population Prospects: The 2015 Revision, Key Findings and Advance Tables. Working Paper No. ESA/P/WP.241.

Winters, J. V. (2011). Human Capital, Higher Education Institutions, and Quality of Life. Regional Science and Urban Economics, 41(5), 446-454.

Levecque, K., et al. (2011). Economic Hardship and Depression Across the Life Course: The Impact of Welfare State Regimes. Journal Health Social Behaviour. 52(2), 262-276.

Li, L. (1995). Subjective Well-Being of Chinese Urban Elderly. International Review of Modern Sociology, 25(2), 1726. Retrieved from http://www.jstor.org/stable/41421083

Maes, M. (2013). Poverty Persistence among the Elderly in the Transition from Work to Retirement. Journal of Economic Inequality. 11, 35-56.

Masud, J., Haron, S. A., Hamid, T. A., \& Zainaludin, Z. (2006). Economic Well Being of the Elderly: Gender Differences. Consumer Interest Annual, 56, 426-431.

Masud, J. and S. A. Haron (2014). Income Disparity among Older Malaysians. Research in Applied Economics. 6(2): 116.

Ministry of Women, Family and Community Development (2013). Active Ageing in Malaysia. http://www.mhlw.go.jp/stf/shingi/2r98520000036yla-att/2r98520000036yqa_1.pdf. Accessed 1 May 2016.

Mirowsky, J., \& Ross, C. E. (2001). Age and the Effect of Economic Hardship on Depression. Journal of Health and Social Behavior. 132-150.

Mirowsky, J. and Ross, C. E. (1999). Economic Hardship across the Life Course. American Sociological Review. 64, 548-69.

Mohd, S. (2014, June). Poverty Issues among Malaysian Elderly. In Proceeding of the Social Sciences Research ICSSR 2014. (e-ISBN 978-967-11768-7-0).

Noone, J. H., Stephens, C., \& Alpass, F. M. (2009). Preretirement Planning and Well-Being in Later Life a Prospective Study. Research on Aging, 31(3), 295-317.

Offer, A. (2006). The Challenge of Affluence: Selfcontrol and Well-being in the United States and Britain Since 1950. Oxford, UK: Oxford University Press.

Oxley, H. (2009). Policies for Healthy Ageing. http://www.oecd-ilibrary.org/social-issues-migrationhealth/policies-for-healthy-ageing_226757488706. Accessed 1 May 2016.

Pudrovska, T., Schieman, S., Pearlin, L. I., \& Nguyen, K. (2005). The Sense of Mastery as a Mediator and Moderator 
in the Association between Economic Hardship and Health in Late Life. Journal of Aging and Health, 17(5), 634660.

Rojas, M. (2008). Experienced Poverty and Income Poverty in Mexico: A Subjective Well-Being Approach. World Development, 36(6), 1078-1093.

Samat, N., Elhadary, Y. A. E., Hijles, F. M., Ghazali, S., \& Sirat, M. (2012). Poverty and Deprivation: Using Geographic Information System in Evaluating the Accessibility of Households to Food Retailers in Penang State, Malaysia. $e$ BANGI, 7(2), 328.

Scott, S. B., Graham-Engeland, J. E., Engeland, C. G., Smyth, J. M., Almeida, D. M., Katz, M. J., ... \& Sliwinski, M. J. (2015). The Effects of Stress on Cognitive Aging, Physiology and Emotion (ESCAPE) project. BMC psychiatry, 15(1), 146.

Lloyd-Sherlock, P. (2000). Old Age and Poverty in Developing Countries: New Policy Challenges. World Development, 28(12), 2157-2168.

Shahar, S., Earland, J., \& Abd Rahman, S. (2001). Social and health profiles of rural elderly Malays. Singapore medical journal, 42(5), 208-213.

Seccombe, K. (2000). Families in Poverty in the 1990s: Trends, Causes, Consequences, and Lessons Learned. Journal of Marriage \& the Family, 62, 1094-1113.

Sherina, M. S., Rampal, L., \& Mustaqim, A. (2004). Cognitive Impairment among the Elderly in a Rural Community in Malaysia. Medical Journal of Malaysia, 59(2), 252-257.

Sherlock, P. L. (2000). Old Age and Poverty in developing Countries: New Policy Challenges. World Development, 28(12), 2157-2168.

Shetty, P. (2012). Grey Matter: Ageing in Developing Countries. The Lancet, 379(9823), 1285-1287.

http://doi.org/10.1016/S0140-6736(12)60541-8

Srivastava, A. \& Mohanty, S.K.. Poverty among Elderly in India. Social Indicator Research. 109(3):493-514

Stephens, C., Alpass, F., \& Towers, A. (2010). Economic Hardship among Older People in New Zealand: The Effects of Low Living Standards on Social Support, Loneliness, and Mental Health. New Zealand Journal of Psychology, 39(2), 49-55.

Stoller, M. \& Stoller, E. P (2003). Perceived Income Adequacy among Elderly Retirees. The Journal of Applied Gerontology, 22 (2), 230-251

Tay, L., \& Diener, E. (2011). Needs and Subjective Well-Being around the World. Journal of personality and social psychology, 101(2), 354.

Tey, N. P., Siraj, S. B., Kamaruzzaman, S. B. B., Chin, A. V., Tan, M. P., Sinnappan, G. S., \& Müller, A. M. (2015). Aging in Multi-Ethnic Malaysia. The Gerontologist, gnv153.

The World Bank (2016). Fertility Rate, Total (Births per Woman).

http://data.worldbank.org/indicator/SP.DYN.TFRT.IN/. Accessed 1 May 2016.

United Nations, Department of Economic and Social Affairs, Population Division (2015). World Population

Prospects: The 2015 Revision, Key Findings and Advance Tables. Working Paper No. ESA/P/WP.241.

Winters, J. V. (2011). Human Capital, Higher Education Institutions, and Quality of Life. Regional Science and Urban Economics, 41(5), 446-454.

Yin-Fah, B. C., Masud, J., Hamid, T. A., \& Paim, L. (2010). Financial Wellbeing of Older Peninsular Malaysians: A Gender Comparison. Asian Social Science, 6(3), 58.

Zhang, L. (2015). Living Arrangements and Subjective Well-Being among the Chinese Elderly. Open Journal of Social Sciences, 3(03), 150. 